\title{
Evaluation of Swallowing Disorder in Ischemic Stroke Patients By Flexible Endoscopic
}

\author{
Nur Indah Lestari', Widjajalaksmi Kusumaningsih', Salim Harris², Susyana Tamin ${ }^{3}$, \\ Retno Asti Werdhani ${ }^{4}$ \\ ${ }^{1}$ Department of Physical Medicine and Rehabilitation, Faculty of Medicine, University of Indonesia, Jakarta \\ ${ }^{2}$ Department of Neurology, Faculty of Medicine, University of Indonesia, Jakarta \\ ${ }^{3}$ Department of Ear, Nose, and Throat-Head and Neck, Faculty of Medicine, University of Indonesia, Jakarta \\ ${ }^{4}$ Department of Community Medicine, Faculty of Medicine, University of Indonesia, Jakarta
}

\begin{abstract}
Introduction: Dysphagia is one of the complications of stroke and closely associated with increasing of aspiration pneumonia. Evaluation of dysphagia was necessary to prevent pneumonia due to aspiration has effectively done by fiberoptic endoscopic evaluation of swallowing (FEES).

Methods: The study was a cross sectional study with convenience sampling. The subjects were stroke outpatients from July to December 2018. The FEES was conducted to assess the swallowing dysfunction and the data were collected.

Results: There was six post ischemic stroke subjects, mean age (SD) was 55.17 (9.13) years and 4 subjects were male. All subjects had standing secretion in pre-swallowing assessment. 3 subjects used nasogastric tube (NGT) to fulfill the intake safely. In swallowing assessment, all subjects had residue at vallecula and/ or pyriformis sinus. 2 subjects had penetration only and 4 subjects had penetration with aspiration. There was inadequate cough reflex in 2 subjects.

Conclusion: Standing secretion and residue became the most dominant findings in post ischemic stroke patients, which a risk to have Aspiration.
\end{abstract}

Keywords: Swallowing Disorder, Stroke, Flexible Endoscopic Evaluation of Swallowing (FEES) 


\section{ABSTRAK}

Pendahuluan: Disfagia adalah salah satu komplikas strok dan berasosiasi lekat dengan peningkatan pneumonia aspirasi. Evaluasi disfagia penting untuk mencegah pneumonia aspirasi, dilakukan dengan efektif oleh endoskopi fiberoptik evaluasi proses menelan (Fiberoptic Endoscopic Evaluation of Swallowing - FEES)

Metode: Penelitian ini adalah penelitian potong lintang dengan convenience sampling. Subjek adalah pasien rawat jalan stroke dari Juli hingga Desember 2019. FEES dilakukan untuk menilai disfungsi penelan dan data dikumpulkan.

Hasil: Terdapat enam subjek pasca stroke iskemik, dengan usia rata-rata (SD) adalah 55.17 (9.13) tahun dan 4 subjek adalah laki-laki. Semua subjek memiliki standing secretion pada penilaian pre-menelan. Tiga subjek menggunakan nasogastrik tube (NGT) untuk memenuhi asupan dengan aman. Pada penilaian menelan, semua subjek memiliki residu pada valekula dan/atau sinus piriformis. Dua subjek hanya memiliki penetrasi dan 4 subjek memiliki penetrasi dengan aspirasi. Terdapat reflek batuk yang tidak adekuat pada 2 subjek.

Kesimpulan: Retensi sekresi dan residu menjadi penemuan yang paling dominan pada pasien pasca stroke iskemik, yang memiliki resiko terjadinya aspirasi.

Kata kunci: Gangguan Menelan, Stroke, Flexible Endoscopic Evaluation of Swallowing (FEES)

\section{Correspondent Detail:}

\section{Nur Indah Lestari}

Email: ndahdurman@gmail.com

Faculty of Medicine University of Indonesia Jakarta, Indonesia

\section{INTRODUCTION}

In 2018, on the endoscopic clinic of Ear Nose and Throat-Head and Neck Surgery (ENT-HNS) Department at Ciptomangunkusumo Hospital, there was 346 patients with neurogenic dysphagia oral phase and pharynx phase confirmed by flexible endoscopic evaluation of swallowing (FEES). 82 of them were caused by stroke. ${ }^{1}$ Dysphagia means difficulty on starting or finishing the swallowing process. ${ }^{2}$ It is caused by some diseases and disorders which affected structure and/ or function of the oral cavity, pharynx, larynx and esophagus. Dysfunction in oral cavity and pharynx often occur simultaneously, it is called oropharynx dysphagia. Beside the anatomical location, it is also important to consider whether the swallowing disorder affect the food transportation or disrupt the airway protection. ${ }^{3}$

The disruption of oral function will inhibit the process of eating, drinking and swallowing. It will be very difficult to move solid or liquid food in the oral cavity, determine whether the bolus is ready to be swallowed, keep the bolus in the oral cavity so that there is no leakage anteriorly or posteriorly and it is difficult to push the food into pharynx. Disruption of the mastication 
process will be difficult when eating solid food. This is usually due to weakness or incoordination of the tongue muscles. Sensory disturbance can also cause the same manifestations, including food retention in the oral cavity after ingestion. Pharyngeal dysfunction results in disruption of swallowing initiation, ineffective bolus impulse and partial bolus retention after swallowing. Velopharyngeal incompetence is the inability to close the velopharyngeal isthmus due to failure of elevation of the mole palate and contraction of the pharyngeal wall to close nasopharynx. In this condition, the bolus may enter the nasal cavity, it caused nasal regurgitation. If the tongue base retraction is weak, the process of pushing food into the pharynx is inadequate resulting in partial or complete retention of the bolus in the pharynx after swallowing. It also could be happened due to weakness of the pharyngeal constrictor muscles. If the epiglottis does not inverse during swallowing, it will become a physical barrier resulting in the retention of a portion of the bolus after vallecula. $^{3}$

Dysphagia is one of the complications of stroke and closely associated with increasing of aspiration pneumonia. The aspiration pneumonia itself become the most common cause of death in stroke patients. ${ }^{4}$ Neurogenic dysphagia refers to difficulty of swallowing the food caused by neurological disorders, either central nervous system, peripheral nervous system or myoneural junction. ${ }^{5}$ Beside infection, malnutrition and dehydration are the other consequences of dysphagia and could also decrease the quality of life and activities of daily living of the patients. ${ }^{6,7}$
In volitional swallowing, there is swallowing network in cerebral cortex which includes insula, cingulate gyrus, prefrontal gyrus, somatosensory cortex and precuneus region. If a stroke happened, one or some of the area could be damaged. The swallowing network will be disturbed and the command center will be declined. ${ }^{6}$

The evaluation of swallowing disorders is an important topic. Many studies have attempted to assess the utility and efficacy of various methods to handle the problem with varying degrees of sensitivity and specificity. ${ }^{8}$ Video fluoroscopy (VFS), FEES and oro-pharyngoesophageal scintigraphy (OPES) are all widely used tools for studying swallowing disorders in the oropharyngeal area. While VFS is still considered to be the gold standard, there are numerous reports in the literature that emphasize the validity of the other two methods. In the literature, there are numerous studies that compare the efficacy of the various diagnostic tools for detecting penetration and aspiration. Some authors demonstrated a good agreement between VFS and FEES, especially regarding aspiration (82.3-90\% agreement). The analysis of FEES vs VFS showed that the sensitivity of FEES was $88 \%$ and specificity was overall lower but was $92 \%$ for detection of aspiration. When the VFS was used as the gold standard, sensitivity of the FEES for laryngeal penetration was $87 \%$, aspiration $96 \%$ and pharyngeal residue was $98 \%$. When the FEES was used as the gold standard, sensitivity of the VFS for laryngeal penetration and aspiration were both $100 \%$, and pharyngeal residue was $96 \%$. Specificity of the VFS for laryngeal penetration was $58 \%$, aspiration $63 \%$ and pharyngeal residue $78 \% .{ }^{9}$ 
FEES is an important test for evaluation of the anatomy of the pharynx and larynx and assessment of the process of swallowing. It has proved to be a significant tool in the assessment of the pharyngeal stage of the swallow process. Numerus studies have highlighted its utility in visualization of the larynx and diagnosis of aspiration. FEES is an easy, efficient and reliable method to evaluate the swallowing status in stroke patients, moreover, in combination with good bedside clinical examination and swallow exercises, it can be a good tool in assessing patients with post-stroke dysphagia. Bedside tests showed $73 \%$ sensitivity and $68 \%$ specificity when correlated with FEES. Moreover combination of voice change and choking/ cough results in sensitivity of $86.5 \%$ and specificity of $75.2 \%{ }^{8}$

Post-stroke rehabilitation and prevention of aspiration pneumonia can be effectively done with the help of FEES. ${ }^{8}$ FEES gave significant results in the evaluation of post-swallowing residues. ${ }^{9}$ The benefit to the patient, in terms of improvement in quality of life, cannot be underestimated. ${ }^{8}$ In this study, we would like to describe the findings of FEES in neurogenic dysphagia after stroke. The results of this study could guide us to give the proper rehabilitation management to improve the swallowing function in stroke patients.

\section{METHODS}

This was a cross sectional study that took the FEES findings in post-stroke dysphagia. The subjects were stroke outpatients who visited our clinic from July to December 2018. The inclusion criteria of subjects in this study were: (1) ischemic stroke patients confirmed by brain imaging, (2) 40-70 years old, (3) had neurogenic dysphagia confirmed by FEES, (4) had good cognition and cooperative. We exclude the patients who had these criteria: (1) patients who had other disease that might cause dysphagia, and (2) had aphasia. Their demographic and clinical characteristics were recorded. The interval between ischemic onset and FEES evaluation were all on subacute onset. The FEES was conducted by ENT-HNS specialist. About the interpretation of FEES, we evaluated the findings in pre-swallowing assessment and swallowing assessment.

In pre-swallowing condition, we assessed: (1) standing secretion, (2) penetration, and (3) aspiration. While in the swallowing condition, we assessed: (1) residue, (2) penetration, (3) penetration with aspiration, and (4) inadequate cough reflex. ${ }^{10}$

Participants' characteristics were summarized as means and standard deviations for continuous data, and frequency counts for categorical data. Based on the calculation of sample, the minimal amounts of sample were 6 subjects.

\section{RESULTS}

Six ischemic stroke patients participated in this study. Of the 6 subjects, mean age (SD) was 55.17 (9.13) years and 4 subjects were male. The mean of stroke onset of the subjects was $3 \pm 1.67$ months. All patients had history of hypertension and 3 subjects had diabetes mellitus. 3 subjects used nasogastric tube (NGT) to fulfill the intake safely, while the others had oral intake. 
Table 1. Characteristics of subjects

\begin{tabular}{lll}
\hline \multicolumn{1}{c}{ Variables } & $\mathbf{n}$ & $\mathbf{X} \pm \mathbf{S D}$ \\
\hline Gender & 4 & \\
\hline Male & 2 & \\
\hline Female & & $55.17 \pm 9.13$ \\
\hline Age (years) & & $3 \pm 1.67$ \\
\hline $\begin{array}{l}\text { Stroke onset } \\
\text { (months) }\end{array}$ & 6 & \\
\hline Hypertension & 0 & \\
\hline Yes & & \\
\hline No & 3 & \\
\hline Diabetes mellitus & 3 & \\
\hline Yes & 3 & \\
\hline No & & \\
\hline Food intake & & \\
\hline Oral & & \\
\hline NGT & & \\
\hline
\end{tabular}

In pre-swallowing assessment of FEES, all subjects had standing secretion at vallecula and/ or pyriformis sinus. Only 2 subjects had penetration and no subjects had aspiration. In swallowing assessment, all subjects had residue at vallecula and/ or pyriformis sinus and some residue could be removed by repeated swallowing. 2 subjects had penetration only and 4 subjects had penetration with aspiration. There was inadequate cough reflex in 2 subjects.
Table 2. Findings of Flexible Endoscopic Evaluation of Swallowing (FEES)

\begin{tabular}{lc}
\hline \multicolumn{1}{c}{ Findings of FEES } & (n) \\
\hline Pre-swallowing assessment & \\
\hline Standing secretion & 6 \\
\hline Penetration & 2 \\
\hline Aspiration & 0 \\
\hline Swallowing assessment & 6 \\
\hline Residue & 2 \\
\hline Penetration & 4 \\
\hline Penetration with aspiration & 2 \\
\hline Inadequate cough reflex
\end{tabular}

\section{DISCUSSION}

FEES assessment showed that all subjects had standing secretion in pre-swallowing assessment and residue in swallowing assessment. Pharyngeal constriction becomes one of the parameters that could be used to differentiate normal swallowing function with swallowing disorder. Dejaeger et al used video fluoroscopy and manometry to evaluate the residue in 25 healthy adults and they concluded that backward tongue thrust, pharyngeal shortening and pharyngeal constriction play a role in determining the presence or absence of residues after swallowing. The backward thrust of the tongue is said to be strongly related to residues in the vallecula, while shortening and constriction of the pharynx is related to residues in pyriformis sinus. ${ }^{11}$ Bolus movement during swallowing depends on the synergistic 
action of the oropharyngeal propulsion and hypopharyngeal suction. The greatest oropharyngeal propulsion force is caused by contact pressure between the tongue and the hard palate during ingestion of the oral phase. Contact that occurs between the anterior part of the tongue and the palate becomes an important part of the tongue movement which will keep the bolus in the oral cavity and ensure proper transport of the bolus. ${ }^{12}$

Huckabee et al said that tongue pressure to the palate will increase submental activation, orolingual pressure and upper pharyngeal pressure. Increased oral pressure will also increase pharyngeal pressure and movement, so it is able to push the bolus from the oral cavity to the pharynx. ${ }^{12}$

The disability caused by penetration and aspiration could change the functional level of the subjects' oral intake. Some researchers claimed that delayed initiation of pharyngeal ingestion is an important indicator of aspiration in stroke survivors. ${ }^{13,14}$ Aspiration is also said to be related to incomplete laryngeal closure due to reduced hyoid and laryngeal excursions. Laryngeal closure is largely determined by arytenoid and epiglottic cartilages to protect the airway. Decreased hyoid and laryngeal excursion will be the independent indicator of aspiration. It is well known that hyoid and laryngeal excursion will result in displacement of the hyoid bone anteriorly and superiorly during the swallowing phase. When the bolus passes through the pharynx, the base of the tongue which is the attachment of the hyoid bone will pull the hyoid bone and larynx anteriorly and superiorly, make the epiglottal retroflection movement to protect the airways. In addition, this epiglottic movement will attract the upper esophageal sphincter so that the bolus can enter the esophagus..$^{3,15,16}$

Perlman et al reported that in $22 \%$ of neurogenic dysphagia patients, there is a decrease in hyoid excursion that is closely related to epiglottic immobility and subsequently results in penetration and aspiration. This is also consistent with the results of the study of Han et al which stated that $73 \%$ of stroke patients with penetration and aspiration show a delayed initiation of swallowing when the bolus enters the pharynx during oral ingestion compared with patients who do not show any penetration or aspiration. Furthermore, during the pharyngeal phase, $88 \%$ of patients with penetration and aspiration showed a reduction in elevation of the hyolarynx when compared to the patients without penetration and aspiration, which was only about $37 \%$. This data shows that patients with penetration and aspiration have minimal airway protection and reduced opening of the upper esophageal sphincter during the pharyngeal swallowing phase. ${ }^{15}$

An inadequate cough reflex is a risk for silent aspiration. Cough is a very important body defense mechanism to increase the secretion of particles and secretions from the airway and protect against the aspiration of foreign substances. Coughing occurs through complex reflex arch stimulation. Starting from the irritation of cough receptors that can be found in the trachea, carina, large airway branches, distal airway and also found in the pharynx. The cough reflex consist of: (1) the afferent pathway, containing sensory nerve fibers that can carry impulses to the medulla, (2) the central pathway, located in the upper brain 
stem and pons, and (3) the efferent pathway, functioning to continue impulses from the cough center to the diaphragm, abdominal wall and muscles. In stroke patients, one of these cough reflex pathways can be disrupted, resulting in an inadequate cough reflex. This risk cause silent aspiration in patients with dysphagia. Miles et al conducted cough reflex test in 148 post-stroke dysphagia patients, $61 \%$ had strong cough reflex, $21 \%$ had weak cough reflex and $18 \%$ did not have cough reflex. ${ }^{17}$

\section{CONCLUSION}

From this study, we concluded that standing secretion and residue in vallecula and/ or pyriformis sinus became the most dominant finding in post-stroke subjects. Aspiration or only penetration happened simultaneously. Lastly, inadequate cough reflex became the less dominant finding.

\section{REFERENCES}

1. Jenks J, Pitts LL. Effects of an Intensive Exercise-Based Swallowing Program for Persons With Parkinson's Disease and Complex Medical History: A Single-Case Experiment. Am J Speech Lang Pathol. 2019; 9: 28(3):1268-1274. doi: 10.1044/2019_ AJSLP-18-0168.

2. Iqbal M, Akil A, Djamin R. Evaluasi proses menelan disfagia orofaring dengan fiberoptic endoscopic examination of swallowing. ORLI.2014; 44: 137-45.

3. Shigematsu T, Fujishima I. Dysphagia and swallowing rehabilitation. Brain
Nerve. 2015;67(2):169-82. doi: 10.11477/ mf.1416200109.

4. Hegland KW, Davenport PW, Brandimore AE, Singletary FF, Troche MS. Rehabilitation of swallowing and cough function following stroke: an expiratory muscle strength training trial. Archives of Physical Medicine and Rehabilitation 2017; 97(8): 1345-51.

5. Ye Q, Liu C, Shi J, You H, Zhao J, Liu J, $\mathrm{Xu} \mathrm{N}, \mathrm{Xu} \mathrm{Z}$ Effect of electro-acupuncture on regulating the swallowing by activating the interneuron in ventrolateral medulla (VLM). Brain Res Bull. 2019 ; 144:132-139.

6. Shaker R. Management of dysphagia in stroke patients. Gastroenterology \& Hepatology. 2011; 7(5): 308-10.

7. Jo SY, Hwang JW, Pyun SB. Relationship between cognitive function and dysphagia after stroke. Ann Rehabil Med. 2017; 41(4): 564-72.

8. Hassan HE, Aboloyoun AI. The value of bedside tests in dysphagia evaluation. Egypt J Ear, Nose, Throat Allied Sci. 2014; 15(3): 197-203.

9. Fattori B, Giusti P, Mancini V, Grosso M, Barillari MR, Bastiani L, et al. Comparison between videofluoroscopy, fiberoptic endoscopy and scintigraphy for diagnosis of oro-pharyngeal dysphagia. Acta Otorhinolaryngologica Italica. 2016; 36: 395-402.

10. Malandraki GA, Rajappa A, Kantarcigil C, Wagner E, Ivey C, Youse K. The intensive dysphagia rehabilitation approach applied to patients with neurogenic dysphagia: a case series design study presented in 
part to the american speech language and hearing association. Arch Phys Med Rehabil. 2016; 97(4): 567-74.

11. Stokely S, Peladeu-Pigeon M, Leigh C, Molfenter SM, Steele CM. The relationship between pharyngeal constriction and post-swallow residue. Dysphagia. 2015; 30: 349-56.

12. Fukuoka $\mathrm{T}$, Ono $\mathrm{T}$, Hori $\mathrm{K}$, Tamine $\mathrm{K}$, Nozaki $S$ et al. Effect of the effortful swallow and Mendelsohn maneuver on tongue pressure production against the hard palate. Dysphagia. 2013; 28: 539-47.

13. Park MK, Lee SJ. Changes in Swallowing and Cough Functions Among Stroke Patients Before and After Tracheostomy Decannulation. Dysphagia. 2018; 33(6):857865. doi: 10.1007/s00455-018-9920-9.

14. Power ML, Hamdy S, Singh S, Tyrell PJ, Turnbull I, Thompson DG. Deglutitive laryngeal closure in stroke patients. J Neurol Neurosurg Psychiatry. 2007; 78: 141-6.

15. Han H, Shin G, Jun A, Park T, Ko D, Choi E. The relationship between the presence of aspiration or penetration and the clinical indicators of dysphagia in poststroke survivors. Ann Rehabil Med. 2016; 40(1): 88-94.

16. Pearson WG, Hindson DF, Langmore SE, Zumwalt AC. Evaluating swallowing muscles essential for hyolaryngeal elevation by using muscle functional magnetic resonance imaging. Int J Radiat Oncol Biol Phys. 2013; 85(3): 735-40.

17. Polverino M, Polverino F, Fasolino M, Ando F, Alfieri A, De Blasio F. Anatomy and neuropathophysiology of the cough reflex arch. Multidisciplinary Respiratory Medicine. 2012; 7: 1-5. 